\title{
The Influence of Employer Branding and Organizational Culture on Employee Engagement with Motivation as Mediators on the Millennials Generation at KAP TSFBR
}

\author{
Benari Saras Wardini and Lenny Christina Nawangsari
}

\section{ABSTRACT}

This study aims to analyze the effect of Employer Branding and Organizational Culture on Employee Engagement with Motivation as a Mediator for the millennials generation working at KAP TSFBR. Respondents in this study are 138 employees who were born between 1980 1995. This research used Descriptive Statistics with Structural Equation Modeling (SEM) analysis methods with variance-based multivariate statistical techniques using PLS.

The results of the study conclude that: 1) Employer branding has a positive and significant effect on employee engagement of millennials generation working at KAP TSFBR, 2) Employer branding has a positive and significant impact on the motivation of millennials working at KAP TSFBR, 3) Organizational culture has a positive and significant impact on employees' engagement of millennials working at KAP TSFBR, 4) Organizational culture has a positive and significant effect on the motivation of millennials working at KAP TSFBR, 5) Motivation has a positive and significant effect on millennials working at KAP TSFBR, 6 ) Employer branding has a positive and significant effect on employee engagement through motivation as a mediator for millennials working at TSFBR KAP, and 7) Organizational culture has a positive and significant effect on employee engagement through motivation as a mediator for millennials working at KAP TSFBR.

Keywords: employee engagement, employer branding, motivation, organizational culture.

\author{
Submitted : July 30, 2021 \\ Published : August 31, 2021 \\ ISSN: 2507-1076 \\ DOI: $10.24018 /$ ejbmr.2021.6.4.1007 \\ Benari Saraswardini \\ Master of Management, Mercu Buana \\ University, Jakarta, Indonesia. \\ (e-mail: b.sarasdini@ gmail.com) \\ Lenny Christina Nawangsari \\ Master of Management, Mercu Buana \\ University, Jakarta, Indonesia. \\ *Corresponding Author
}

\section{INTRODUCTION}

Having a good reputation is very important for companies to be able to continue to thrive. Nowadays, businesses are very competitive and are supported by the development of information and technology that is extremely fast, so companies have to undertake strategies that can build a reputation that is good for the entire stakeholder interests. Because of the current condition, top-level management is increasingly aware of the importance of having qualified and productive employees as well as those who suit the culture of the company.

The challenges of companies in the current era of information technology are increasingly complex and varied. Currently, Generation Y or millennials have entered the age of productivity and began to dominate the field of work in companies. In general, millennials have high self-trusted, multi-tasking, and tech-savvy. These characteristics make them easily connect with the world through social media and other various media information. Thus, this condition influences how they view in determining a career or occupation. The existence of information that is easy for them to get makes them have many choices, so if they don't get a suitable place to work, they will easily leave and look for a better company. It is written on Riyanto and Setyani research [1], Zarim and Zaki found that generation Y or millennials prefer to work for organizations where they can work with technology, communicate via email, and social media.

Based on the condition, companies need to start considering strategies to attract candidates who can adjust to the culture of the organization. After getting suitable candidates, the company needs to create relationship stronger with the employees. Having a strong relationship with employees will create a mutual relationship between employees and the company so that employees will feel motivated to work. Furthermore, they will proudly tell positive things about the company and its work so that the productivity will increase and companies' image is getting better.

However, the challenge faced by companies today is creating employee engagement for the millennial generation, so they can support the company in long term. Companies need to consider what appeals to millennial employees so that they have an interest in doing their best and have high motivation to contribute to the company's success. Therefore, companies need to consider making employee engagement strategies for candidates and employees, especially millennials by paying attention to the aspirations of candidates and considering what the company can provide to 
employees. This reason is reinforced by the increasing number of millennials who have dominated various field sectors in recent years based on data from the 2019 National Labor Force Survey (SAKERNAS). It stated that Generation $\mathrm{X}$ and Generation $\mathrm{Y}$ (millennials) have the highest proportion in 17 business sectors. It means the Millennial generation is ready to fill the position of previous generations and dominate all business sectors [2]. The condition is also experienced by KAP TSFBR, which provides external audit services to clients. From 312 professional staff of KAP TSFBR, 190 people $(61 \%)$ are millennials. This fact makes the author interested in examining more deeply the behavior of the millennials generation towards the companies where they work.

Historically, KAP TSFBR is one of the oldest accounting firms in Indonesia, which began providing audit services to its clients in 1979. Since 1992, this firm has been appointed as a member of BDO International Limited, an international accounting network headquartered in Brussels. As of 2020, BDO International Limited has members in 167 countries and territories with 1,658 offices and is supported by 91,054 professional workers. With the existence attached to the name of BDO, as a member of BDO in Indonesia, KAP TSFBR aims to be able to build a good reputation through the support of quality human resources and have a strong relationship with the company, so it can contribute to the development of KAP TSFBR.

From a branding perspective, KAP TSFBR as a member of the network of BDO International is quite well-known supported by its top fifth position globally, as well as the results of a survey of the World Ranking in the year 2019 by the International Accounting Bulletin (IAB) [3].

With the reputation attached to KAP TSFBR, it is expected that it can attract and strengthen the relationship between the millennial generation employees to KAP TSFBR so that it becomes motivation to work well in the long term. In addition, in terms of the organizational culture that exists at KAP TSFBR to support the company's goals, it is expected to be a driving force for employees to work well because organizational culture is the soul of the organization and the soul of the members of the organization [4].

The problem faced today is employee engagement has not been optimal, especially for employees from the millennials generation, so it needs to be improved. By paying attention to all the uniqueness of these millennials employees, the company seeks to find the right strategy to meet the aspirations of its employees so that the company can work well and have high motivation to support the company's progress.

In line with the phenomena that exist in KAP TSFBR, the authors choose the object of research with a focus on the company's efforts to increase employee engagement in the millennials generation through employer branding strategies and organizational culture with motivation as a mediator.

Based on the results of a pre-survey conducted on 17 respondents who work at KAP TSFBR who were born between 1980-1995 or who belong to the millennial group, it shows that there is a tendency that employer branding and organizational culture have not optimally motivated millennial employees to increase employee engagement so that there is still an employee engagement gap that occurs at
KAP TSFBR, especially for millennial employees. Therefore, the authors are interested in conducting more indepth research on "The Influence of Employer Branding and Organizational Culture on Employee Engagement and Motivation as a Mediator for the Millennial Generation at KAP TSFBR".

\section{LITERATURE REVIEW AND HYPOTHESIS}

\section{A. Employee Engagement}

Based on Febriansyah and Ginting research, Gallup in Schermerhorn et al. defines that employee engagement as a gesture of work positively that described work with passion and feel have a relationship that is deep with an employer [5]. Meanwhile the previous research, on Suryaningrum et al., [6], Kahn explains the theory of the relationship and involvement that occurs as closely as physical, cognitive, and emotional of a person with the role of his job, which is then referred to as the involvement of employees (employee engagement). It is written in Riyanto and Setyani research, [1], Graban and Thomas stated that Engagement is important for employees and organizations for involvement at much higher yield productivity of employees are higher, increase quality with more little mistakes, much higher profitability, and the possibility of success of a business that is high. In addition, Kartono [7] agree with Schaufeli et al., that define employee engagement as a state of mind positive which is characterized by vigor, dedication, and absorption, with explanation in detail is as follows:

1. Vigor: Reflects the readiness to devote himself to work and is always energetic at work and continues to try to face every task no matter how difficult it is because he has mental resilience at work.

2. Dedication: A feeling that is full of meaning, inspiration, and pride. The sacrifice of energy, mind, and time for the success of an effort to achieve a goal.

3. Absorption: The condition where a person drowning at work, with full concentration and interest in the depth of the work, so the time flies fast and individual hard detach themselves from the job.

\section{B. Employer Branding}

Simon Barrow and Richard Mosley describe that employer brand in an employer's reputation as a place to work, and their employee value proposition, as opposed to the more general corporate brand reputation and value proposition to customers [8]. Based on Kusuma and Prasetya research [9], Lloys define that employer branding as the total of a company's efforts to communicate to. existing and prospective employees about the company as a desirable place to work at. Meanwhile, it is written on Amelia study [10], Brett Minchington illustrates that the employer brand is the perception of your organization as a "great place to work". It represents the sum of thoughts and feelings that people associate with an employer, and stakeholders both active and passive candidates, clients, customers, and others The other research said that employer branding consists of Employer branding is composed of several marketing strategies that help in the process of attracting employees to the neverending recruitment cycle for the numerous job vacancies. This is the use of some ideas of innovation that aims to help 
develop the image of the organization and create an entity that is very interesting that not only attracts a lot of members but also ensures that they fit with the skills that are needed for the jobs are available. These innovative ideas are not limited and come in various forms that are all aimed to maintain the supply of employees for companies [11]. Love and Singh in Chawla study state that the development of employer branding strategies has a positive influence on employee engagement[12].

\section{Organizational Culture}

Based on Wibowo studies, according to Edgar Schein, organizational culture is a philosophy that underlies the policy organization, the rules of interaction, and the feeling or atmosphere which is brought by the preparation of the organization physically[13]. Meanwhile, Sutrisno wrote on his study [4], Kilmann defines that organizational culture is a set of system values, beliefs, assumptions, or norms that have been affected, agreed and followed by the members of the organization. In organizational culture, values are socialized and internalized within members, animating each person in the organization. Thus, organizational culture is the soul of the organization and the soul of the members of the organization. On the same study, Miller in Sutrisno state that, there are several points of primary values that should exist in each company which if managed properly can become a positive organizational culture, and will result in effectiveness, innovation, loyalty, and productivity [4]. By the research of Prasetya [14], G. Graham and Siswadi stated that organizational culture is the norms, beliefs, attitudes, and philosophies of the organization. From some of the definitions above, it can be seen that organizational culture is a pattern of organizational beliefs and values that are internalized by each employee in carrying out their duties and responsibilities. Meanwhile, as written on Purwanta and Nawangsari according to Robbin \& Judge stated that organizational culture is related to a system within an organization or company that is held and interpreted together by all members or employees so that it can distinguish an organization from other organizations. Furthermore, there are 7 main characteristics and are the core of organizational culture, namely innovation and risk-taking, attention to detail, result-oriented, people-oriented, team-oriented, aggressiveness, and stability [15].

\section{Motivation}

The research conducted by Purwanta and Nawangsari found that David McClelland explains the theory of needs which is commonly referred to as McClelland's theory of needs, 3 facts influence work motivation, namely the need for achievement, the need for power, and the need for affiliation [15]. On the other theory of motivation by Newstrom as written on Wibowo [13], states that work motivation is the result of internal and external forces that make employees choose the appropriate way to act and use certain attitudes that will be directed at the goals of the organization/company. The motivation indicators according to Newstrom consist of:

1. Engagement is an employee's promise to show the level of enthusiasm, initiative, and effort to continue.

2. Commitment is a level where employees bind to the organization and demonstrate organizational citizenship actions.
3. Satisfaction. Satisfaction is a reflection of fulfilling psychological contracts and meeting expectations at work.

4. Turnover is the loss of valued workers.

Meanwhile, According to the study of Nawangsari and Sutawidjaya describe that work motivation by George and Jones, is defined as an encouragement to someone to be psychologically Determine in the direction of his behavior [16].

\section{E. Conceptual Framework}

From the theoretical analysis and empirical studies, it can be stated that there is a relationship between Employer Branding, Organizational Culture, Motivation, and Employee Engagement variables which can be described in a conceptual framework diagram as follows:

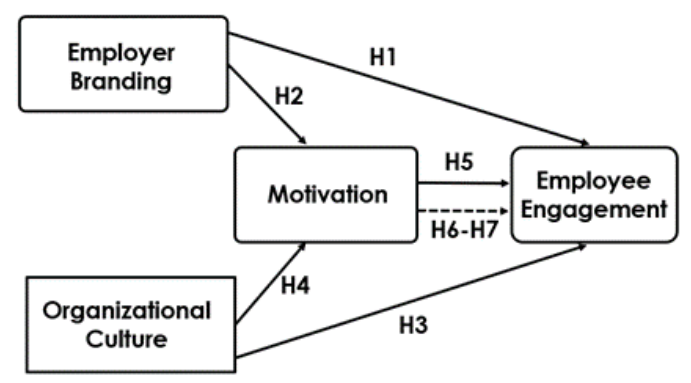

Fig. 1. Conceptual Framework.

\section{F. Hypothesis}

H1: Employer branding has a positive and significant effect on employee engagement in the millennials generation in KAP TSFBR.

H2: Employer branding has a positive and significant effect on employee motivation in the millennials generation in KAP TSFBR.

H3: Organizational culture has a positive and significant effect on employee engagement in the millennials generation in KAP TSFBR.

H4: Organizational culture has a positive and significant effect on the motivation of millennials employees in KAP TSFBR

H5: Motivation has a positive and significant effect on employee engagement in the millennials generation in KAP TSFBR

H6: Employer branding has a positive and significant effect on employee engagement through motivation as a mediating variable in the millennials generation in KAP TSFBR.

\section{MethodOlOGY}

The author uses a quantitative approach in this study. According to Sudjana \& Ibrahim [17], quantitative research comes from an assumption which then sets variables, analyzes them using a measurable research model. According to Sugiyono [18] states that the quantitative approach is research based on the philosophy of positivism to examine certain populations or samples and take random samples with data collection using instruments, data analysis is statistical. In this study, employee engagement (Y2) is placed as an 
independent variable, while the independent variables in this study are employer branding (X1) and organizational culture (X2), and motivation is the mediating variable (Y1).

In this study, the sample used was quota sampling taken from millennials generation employees who worked at KAP TSFBR were born between $1980-1995$ as many as 138 people. In the research of Bencsik et al., [19] it is stated that generation $\mathrm{Y}$ or millennials are a group who was born between 1980-1995.

This study uses the Structural Equation Modeling (SEM) data analysis method with the Smart-PLS (Partial Least Square) program. According to Hair et al., SEM-PLS is another alternative to the Structural Equation Model which is often referred to as variant-based SEM. SEM-PLS analysis consists of two sub-models, namely the measurement model or often called the outer model, and the structural model or often called the inner model which aims to examine the relationship between variables that exist in a model, both between indicators and their constructs, or the relationship between constructs[20].

\section{RESUlt AND Discussion}

\section{A. Characteristics of Respondents}

Characteristics description of the respondents in the study is based on the type of gender, year of birth, sex, position, length of work, and office locations. Respondents in the study of this are employees of KAP TSFBR generation of millennials were born between the years 1980-1995 as many as 138 people, so it can be obtained a description of the characteristics of the respondents as follows:

\begin{tabular}{cccc}
\multicolumn{4}{c}{ TABLE I: CHARACTERISTICS OF RESPONDENTS } \\
\hline \multirow{2}{*}{ Category } & Description & $\begin{array}{c}\text { Amount } \\
\text { (person) }\end{array}$ & Percentages \\
\hline \multirow{3}{*}{ Year of birth } & $1980-1985$ & 12 & $8,7 \%$ \\
& $1986-1990$ & 30 & $21,7 \%$ \\
Sex & $1991-1995$ & 96 & $69,6 \%$ \\
& Male & 67 & $49 \%$ \\
Length of & Female & 71 & $51 \%$ \\
work & $1-3$ year & 9 & $6,5 \%$ \\
& $3-5$ year & 34 & $24,6 \%$ \\
& $>5$ year & 48 & $34.8 \%$ \\
Position & Support Staff & 26 & $34,1 \%$ \\
& Assistant & 23 & $18,8 \%$ \\
& Auditor in-charge & 67 & $16,7 \%$ \\
& Manager in-charge & 22 & $48,6 \%$ \\
& Head office & 89 & $64 \%$ \\
Location & South Jkt branch & 29 & $19 \%$ \\
& West Jkt branch & 9 & $7 \%$ \\
& Bandung branch & 14 & $10 \%$ \\
\hline
\end{tabular}

Data Source: Primary Data Processed, 2021.

\section{B. Outer Model}

The analysis of the results of the outer model test carried out is as follows:

\section{1) Convergent validity (outer loading)}

Based on the results of the convergent validity test in Fig. 2 , there are 14 indicators on the employer branding variable (X1) having a loading factor $>0.7$ with a value between 0.720 to 0.839 so that it is considered to meet the specified requirements and can be used for further analysis. In the organizational culture variable (X2) 11 indicators have a loading factor $>0.7$ between 0.731 to 0.839 so that they can be considered eligible for further research analysis. On the motivation variable (Y1) with 9 indicators that have a loading factor $>0.7$ with a value between 0.727 to 0.808 which can meet the requirements for use in further research analysis. Likewise, the employee engagement variable (Y2) has 6 indicators with a loading factor value $>0.7$ with a value between 0.790 to 0.863 so that it can meet the specified requirements for further analysis

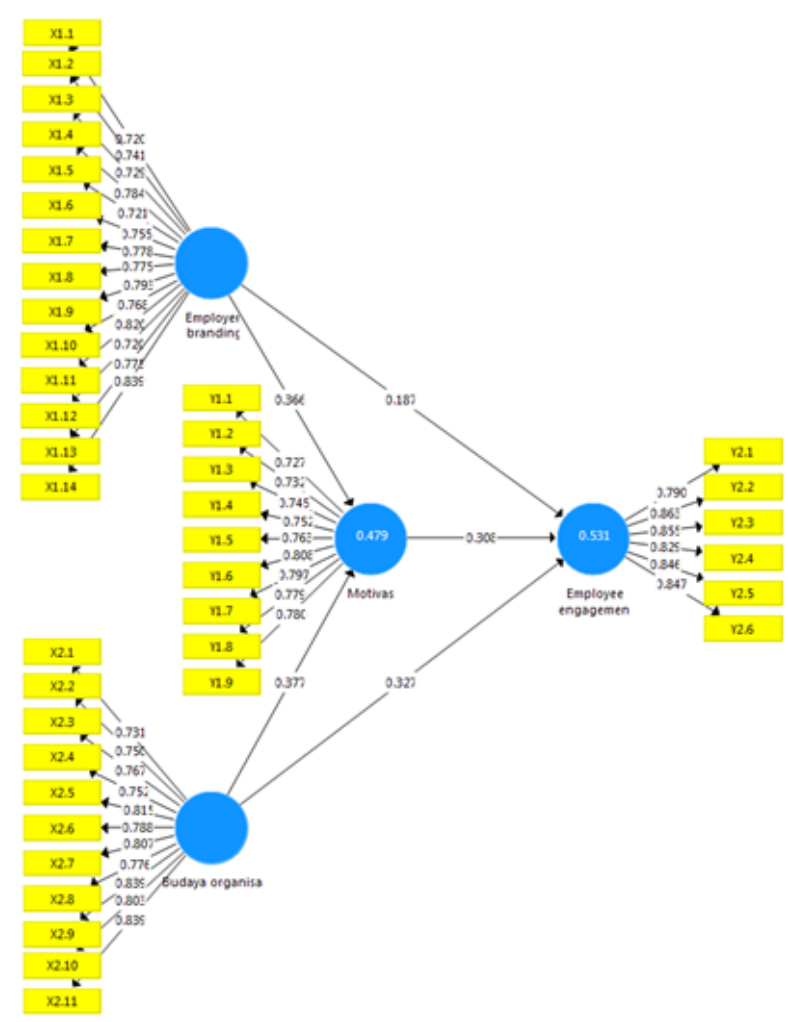

Fig. 2. Convergent validity test results.

\section{2) Cronbach's Alpha and Composite Reliability}

Testing composite reliability aims to test the reliability of the indicators on a variable. In addition, the reliability test can also be strengthened by using Cronbach's alpha value to test the reliability of the instrument in a research model [20].

TABLE II: CRONBACH'S ALPHA AND COMPOSITE RELIABILITY

\begin{tabular}{cccc}
\hline Variable & $\begin{array}{c}\text { Cronbach's } \\
\text { Alpha }\end{array}$ & $\begin{array}{c}\text { Composite } \\
\text { Reliability }\end{array}$ & Information \\
\hline $\begin{array}{c}\text { Employer } \\
\text { branding }\end{array}$ & 0.946 & 0.952 & Reliable \\
$\begin{array}{c}\text { Organizational } \\
\text { culture }\end{array}$ & 0.939 & 0.948 & Reliable \\
$\begin{array}{c}\text { Motivation } \\
\text { Employee }\end{array}$ & 0.912 & 0.927 & Reliable \\
engagement & 0.915 & 0.934 & Reliable \\
\hline
\end{tabular}

Based on Table II, it can be seen that all variables in this research model are reliable because the composite reliability value > 0.7 and Cronbach's alpha value > 0.7 so that all variables have met the criteria and it can be concluded that all variables have a good level of reliability [20].

\section{3) Average Variance Extracted (AVE) Test}

Based on Table III, it can be seen from the AVE value in the Employer branding variable of $0.588>0.5$ while the organizational culture variable has a value of $0.622>0.5$ then the Motivation variable is $0.586>0.5$ and the Employee 
engagement variable is $0.703>0,5$. Thus, because all variables have an AVE value $>0.5$, it can be stated that the variables used in this study already have discriminant validity that has met the requirements[21].

\begin{tabular}{ccc}
\multicolumn{3}{c}{ TABLE III: AVERAGE VARIANCE EXTRACTED } \\
\hline Variable & $\begin{array}{c}\text { Average Variance } \\
\text { Extracted (AVE) }\end{array}$ & Information \\
\hline Employer branding & 0.588 & Valid \\
Organizational culture & 0.622 & Valid \\
Motivation & 0.586 & Valid \\
Employee engagement & 0.703 & Valid \\
\hline
\end{tabular}

\section{Inner Model Test}

The inner model test is the development of a concept and theory-based model to analyze the relationship between exogenous and endogenous variables which has been described in a conceptual framework [20]. A structural model test was conducted to assess the coefficient of determination $\left(\mathrm{R}^{2}\right)$. The results of $\mathrm{R}^{2}$ between 0 to 1 with a coefficient of determination close to 1 indicate that the model is more suitable. The following is the value of the coefficient of determination $\left(\mathrm{R}^{2}\right)$ in this study:

\begin{tabular}{ccc}
\multicolumn{3}{c}{ TABLE IV: DETERMINATION R ${ }^{2}$} \\
\hline & R-Square & R-Square Adjusted \\
\hline Motivation & 0.479 & 0.471 \\
Employee engagement & 0.531 & 0.521 \\
\hline
\end{tabular}

Based on Table IV, it can be seen that the $\mathrm{R}^{2}$ value for motivation (Y1) is 0.479 which means that it is included in the moderate category. Therefore, it can be concluded that the variable Employer branding (X1) and organizational culture (X2) have a significant impact on motivation (Y1). In other words, the motivational construct variable can be explained by employer branding and organizational culture by 0.479 or $47.9 \%$. While the remaining $52.1 \%$ is explained by other factors not observed in this study. The $\mathrm{R}^{2}$ value for Employee engagement (Y2) is 0.531 which means that it is included in the moderate category. So it can be concluded that the variables Employer branding (X1), Organizational culture (X2), and motivation (Y1) have a significant impact on employee engagement (Y2). Therefore, it can be explained that the employee engagement construct variable can be explained by Employer branding and organizational culture of 0.531 or $53.1 \%$, while the remaining $46.9 \%$ is explained by other factors not observed by this study.

TABLE V: COEFFICIENT CORRELATION

\begin{tabular}{|c|c|c|c|}
\hline Hypothesis & t- statistics & p-values & Result \\
\hline $\begin{array}{l}\text { Employer branding -> } \\
\text { Employee engagement }\end{array}$ & 2.018 & 0.044 & $\begin{array}{c}\text { Positive } \\
\text { Significant }\end{array}$ \\
\hline $\begin{array}{c}\text { Employer branding -> } \\
\text { Motivation }\end{array}$ & 3.761 & 0.000 & $\begin{array}{l}\text { Positive } \\
\text { Significant }\end{array}$ \\
\hline $\begin{array}{c}\text { Organizational culture -> } \\
\text { Employee engagement }\end{array}$ & 2.915 & 0.004 & $\begin{array}{l}\text { Positive } \\
\text { Significant }\end{array}$ \\
\hline $\begin{array}{c}\text { Organizational culture -> } \\
\text { Motivation }\end{array}$ & 4.115 & 0.000 & $\begin{array}{c}\text { Positive } \\
\text { Significant }\end{array}$ \\
\hline $\begin{array}{c}\text { Motivation -> Employee } \\
\text { engagement }\end{array}$ & 3.023 & 0.003 & $\begin{array}{c}\text { Positive } \\
\text { Significant }\end{array}$ \\
\hline $\begin{array}{c}\text { Employer branding -> } \\
\text { Motivation -> Employee } \\
\text { engagement }\end{array}$ & 2.243 & 0.025 & $\begin{array}{c}\text { Positive } \\
\text { Significant }\end{array}$ \\
\hline $\begin{array}{l}\text { Organizational culture - } \\
>\text { Motivation -> Employee } \\
\text { engagement }\end{array}$ & 2.269 & 0.024 & $\begin{array}{c}\text { Positive } \\
\text { Significant }\end{array}$ \\
\hline
\end{tabular}

Based on Table $\mathrm{V}$, the results of the hypothesis testing the direct influence of employer branding (X1) on employee engagement (Y1) has a t-statistic value of 2018>1.96, p-value $0.044<0.05$ then $\mathrm{H} 1$ is accepted, meaning that employer branding has a positive effect and significant impact on employee engagement of millennial generation at KAP TSFBR.

Employer branding (X1) on motivation (Y1) has a tstatistic value of $3,761>1.96$ and $p$-value $0.000<0.05$, then $\mathrm{H} 2$ is accepted, meaning that employer branding has a positive and significant effect on the motivation of millennial employees at KAP TSFBR.

Organizational culture (X2) on employee engagement (Y2) has a t-statistic value of 2,915>1.96, p-value $0.004<0.05$ then $\mathrm{H} 3$ is accepted, meaning that organizational culture has a positive and significant effect on employee engagement of millennial generation employees at KAP TSFBR.

Organizational culture (X2) on motivation (Y1) has a tstatistic value of $4.115>1.96$, p-value $0.000<0.05$, then $\mathrm{H} 4$ is accepted, meaning that organizational culture has a positive and significant effect on the motivation of millennial generation employees at KAP TSFBR.

Motivation (Y1) on employee engagement (Y2) has a tstatistic value of $3.023>1.96$, p-value $0.003<0.05$, then H5 is accepted, meaning that motivation has a positive and significant effect on employee engagement of the millennial generation at KAP TSFBR.

The results of hypothesis testing the indirect effect of employer branding (X1) on employee engagement (Y2) through motivation (Y1) has a t-statistic value of 2,243>1.96, p-value $0.025<0.05$ then $\mathrm{H} 6$ is accepted, meaning that employer branding affects positive and significant on employee engagement of millennial generation employees at KAP TSFBR with motivation as a mediator.

Furthermore, organizational culture (X2) on employee engagement (Y2) through motivation (Y1) has a t-statistic value of 2.269 $>1.96$, p-value $0.024<0.05$ then $\mathrm{H} 7$ is accepted, meaning that organizational culture has a positive and significant effect on employee engagement through the motivation of millennial generation employees at KAP TSFBR.

\section{CONCLUSION AND SUGGESTION}

\section{A. Conclusion}

Based on the results of research and discussion that have been described in the previous chapter, it can be concluded that the results of the study are as follows:

1) Employer branding has a positive and significant effect on employee engagement. This shows that being able to work flexibly can build a work environment that is not boring so that it can strengthen the relationship between millennial employees and KAP TSFBR.

2) Employer branding has a positive and significant effect on motivation in the millennial generation. This shows that being able to work flexibly can build a pleasant work environment for millennial generation employees so that they can increase the work motivation of millennial employees at KAP TSFBR.

3) Organizational culture has a positive and significant 
impact on millennial generation employee engagement. This shows that always trying to work effectively and efficiently, will improve the performance of millennial generation employees at KAP TSFBR.

4) Organizational culture has a positive and significant effect on the motivation of the millennial generation. This

shows that organizational culture that can increase work motivation is to provide opportunities for millennial employees to work effectively and efficiently.

5) Motivation has a positive and significant impact on millennial generation employee engagement. This shows that high employee motivation can be done by increasing cooperation to accommodate the need for affiliation for the millennial generation who work at KAP TSFBR.

6) Employer branding has a positive and significant effect on employee engagement through motivation as a mediating variable at KAP TSFBR.

7) Organizational culture has a positive and significant effect on employee engagement with motivation as a mediating variable at KAP TSFBR.

\section{B. Suggestion}

The author thinks that there are still have many weaknesses in this study. The limitations of this research still require further development. If it is seen from $\mathrm{R}^{2}$ which is still low (only 50\%), then research can be done by developing other variables.

Another limitation in this research is the object of research so that it can be developed on the object of research at the big four Public Accounting Firm so that it will be able to provide a more comprehensive picture of knowledge.

It needs to be explored more deeply related to the number of millennial generation employees who work in Public Accounting Firms (KAP) in Indonesia. The lack of interest of the millennial generation in Indonesia to become auditors needs further research.

\section{REFERENCES}

[1] S. Riyanto and A. Setyani, "Factors Affecting Indonesian Millenial Workers 'Engagement with Companies," vol. 13, no. 8, pp. 690-705, 2020.

[2] N. Syaifudin and A. Andini, "Milenial siap geser generasi X." 2020, [Online]. Available: https://lokadata.id/artikel/milenial-siap-gesergenerasi-X.

[3] "Reanda-International-21-amongst-international-accountingnetworks." https://reanda-netherlands.com/reanda-international-21international-accounting-2020/.

[4] E. Sutrisno, Budaya Organisasi. Prenadamedia Group, 2018.

[5] H. Febriansyah and H. Ginting, Tujuh Dimensi Employee Engagement, Pertama. Prenada, 2020.

[6] D. Suryaningrum, B. Tunas, and C. Yohana, "Organizational Culture and Leadership, Influence to Employee Engagement in Z Generation," 2019, doi: 10.4108/eai.1-4-2019.2287236.

[7] Kartono, Buku Personality Employee Engagement Emotional Intellegence Job Burnout Turnover Intention. Sleman, Yogyakarta: Deepublish, 2017.

[8] Wikipedia, "Employer Branding - Wikipedia." [Online]. Available: http://de.wikipedia.org/wiki/Employer_Branding.

[9] T. Kusuma and A. Prasetya, "Penerapan Strategi Employer Branding Dan Employee Value Proposition Untuk Menciptakan Employee Engagement (Studi Pada PT Bank Central Asia Tbk)," J. Adm. Bisnis, vol. 50, no. 5, pp. 143-151, 2017.

[10] A. Amelia, Employer Branding - When HR is the new marketing. PT Kompas Media Nusantara, 2018.

[11] T. Al Badawy, V. Fahmy, and M. Magdy, "Can Employer Branding Surge the Retention and Motivation of Egyptian Employees?," Compet. Forum, vol. 13, no. 2, p. 253, 2015.
[12] P. Chawla, "Impact of employer branding on employee engagement in business process outsourcing (BPO) sector in India: mediating effect of person-organization fit," Ind. Commer. Train., vol. 15, no. 1, pp. 3549, 2019, doi: 10.1108/ICT-06-2019-0063.

[13] Wibowo, Budaya Organisasi. PT Rajagrafindo Persada, 2010.

[14] R. Y. Prasetya, "The Influence of Leadership Style , Organizational Culture, and Work Motivation on Organizational Citizenship Behavior for Environment ( OCBE ) of the Directorate General of Fiscal Balance 's Employees," Int. J. Innov. Sci. Res. Technol. ISSN, vol. 4, no. 12, pp. 641-647, 2019.

[15] F. F. Purwanta and L. C. Nawangsari, "The Influence of Work Motivation, Organizational Culture, and Work Environment on the Work Discipline of Employees PT Inti Karya Persada Tehnik," Int. J. Sci. Res. Publ., vol. 8, no. 12, pp. 86-92, 2018, doi: 10.29322/ijsrp.8.12.2018.p8415.

[16] L. C. Nawangsari and A. H. Sutawidjaya, "Talent management in mediating competencies and motivation to improve employee's engagement," Int. J. Econ. Bus. Adm., vol. 7, no. 1, pp. 140-152, 2019, doi: 10.35808/ijeba/201.

[17] Sudjana and Ibrahim, Penelitian dan Penilaian Pendidikan, 7th ed. Bandung: Sinar Baru Algensindo, 2012.

[18] Sugiyono, Metode Penelitian Kuantitatif, Kualitatif, dan R\&D. Bandung: Alfabeta, 2016.

[19] A. Bencsik, T. Juhász, and G. Horváth-Csikós, "Y and Z Generations at Workplaces," J. Compet., vol. 6, no. 3, pp. 90-106, 2016, doi: 10.7441/joc.2016.03.06.

[20] I. Ghozali and H. Latan, Partial Least Squares Konsep, Teknik Dan Aplikasi menggunakan program SmartPLS 3.0 untuk penelitian empiris. Universitas Diponegoro, Semarang, 2015.

[21] D. Wise, "Work from Home During and After Coronavirus: How Online Freelance and Entrepreneurship Can Get You Through the COVID-19 Crisis." 2020. 